\title{
PENGARUH KEPEMIMPINAN, MOTIVASI DAN STRES KERJA TERHADAP KINERJA KARYAWAN PADA DINAS PEKERJAAN UMUM DAN PENATAAN RUANG PROVINSI SUMATERA BARAT
}

\author{
Rian Rional, Maria Magdalena \\ Sekolah Tinggi Ilmu Ekonomi KBP \\ Rianrional19@gmail.com
}

\begin{abstract}
In the problem of employee work performance in the West Sumatra industrial and trade department. In the company a productivity that does not support work productivity. the number of employees who do not understand the work done, employees are also not responsible for a job. because of the large amount of work done by employees given by superiors. The purpose of this study was to determine the effect of transformational leadership style and transactional leadership style on the employee performance of HR Division employees at the Department of Public Works of West Sumatra Spatial Planning. This type of research is quantitative. The population of this study were employees of the Human Resources Division of the Department of Public Works, West Sumatra Spatial Planning with 81 samples. Data is processed using multiple linear regression using a questionnaire. The results showed that transformational leadership style had a positive and significant effect on employee performance with a value of $t$ arithmetic 2,281 > t table 1,990, and sig value 0,001 $<0.05$ and transactional leadership style had a positive and significant effect on employee performance decisions with 3,066 $t$ count, $>$ t table 1.990, and sig value $0.003<0.05$ and suggestions for further researchers to be able to use this research as a reference which will later provide a comparison in conducting further research
\end{abstract}

Keywords: Leadership, Motivation, Work Stress, Employee performance

\section{PENDAHULUAN}

Sumber daya manusia merupakan kondisi yang paling perlu dalam pencapaian suatu tujuan instansi pemerintah. Instansi pemerintah bertujuan mampu untuk dapat mengolah dan menggerakan suatu sumber daya manusia yang memiliki secara efektif, efisien dan produktif. Peran manusia berkualitas suatu kelompok sebagai karyawan yang memegang penting dalam suatu oganisasi. Karena hidup dan tidak jalannya suatu organisasi instansi hanya tersangkut pada karyawan. Karyawan merupakan faktor-faktor yang luar biasa dalam suatu instansi dan juga faktor penentu dalam pencapain orientasi instansi dan penentu jalannya suatu organisasi.

Penelitian ini dilakukan pada

Dinas Pekerjaan Umum Dan Penataan Ruang Provinsi Sumatera Barat atau lebih di kenal dengan Dinas Pekerjaan Umum (PU), merupakan suatu dinas pelaksana tugas-tugas pemerintahan yang dipimpin oleh seorang Kepala Dinas yang melaksankan tugasnya serta bertanggung jawab kapada Wali Kota melalui Sekretaris Daerah.

Menurut Astianto, (2014), mengatakan bahwa kinerja merupakan perbandingan hasil kerja yang dicapai oleh karyawan dengan 
standar yang telah ditentukan. Kinerja juga berarti hasil yang dicapai oleh seseorang, baik kuantitas maupun kualitas dalam suatu organisasi sesuai dengan tanggung jawab yang diberikan kepadanya.

Kepemimpinan merupakan
suatu ilmu yang menjalankan
perjuangan atau menghadapi
kesuksesan. Kepemimpinan artinya
sebagai tujuan memengaruhui serta
memberikaktivitas contoh oleh
pemimpin untuk pengikutnya
berkualitas berupaya mencapai
orientasi kelompok.

Suwati, (2013), manyatakan motivasi adalah daya pendorong yang mengakibatkan seseorang anggota organisasi mau dan rela untuk mengerahkan kemampuan dalam bentuk keahlian atau keterampilan, tenaga dan waktunya untuk menyelenggarakan berbagai kegiatan yang menjadi tanggung jawabnya dan menunaikan kewajibannya, dalam rangka pencapaian tujuan dan berbagai sasaran organisasi yang telah ditentukan sebelumnya.

Stres berpengaruh positif serta negatif terhadap kinerja karyawan. Seperti yang diungkapkan Hotiana, (2018). Stres memiliiki dampak positif dan negatif. Pengaruh positif stres pada tingkat rendah sampai pada tingkat moderat bersifat fungsional dalam arti berperan seperti penggerak peningkatan kinerja karyawan. Sedangkan pada dampak negatif stres tingkat yang tinggi adalah penurunan pada kinerja karyawan draktis.

Astianto, (2014). Penelitian ini Pengaruh stres kerja dan beban kerja terhadap kinerja karyawan pdam surabaya. Hasil penelitian ini bahwa stres kerja dan beban kerja secara simultan berpengaruh signifikan terhadap kinerja karyawan.

Susanto, (2016). Penelitian ini Pengaruh Kepemimpinan Dan Motivasi Terhadap Kinerja Karyawan CV. Adhi Baskoro Perkasa Pangkalanbun. Hasil penelitian ini menunjukkan bahwa kepemimpinan dan motivasi memiliki pengaruh positif terhadap kinerja karyawan.

Stres kerja merupakan perasaan yang tertekan yang dialami keryawan dalam suatu perusahaan yang dihadapi pekerjaannya. Situasi stres kerja yaitu banyaknya pikiran pekerjaan yang dirasakan terlalu berat, waktu kerja yang mendesak, kualitas pengawasan yang rendah, iklim kerja yang tidak sehat, otoritas yang tidak memadai yang berhubungan dengan tangguang jawab, konflik kerja, perbedaan nilai karyawan dengan pemimpin yang frustasi dalam kerja.

Fenomena yang terjadi pada Dinas Pekerjaan Umum Dan Penataan Ruang Provinsi Sumatera Barat. Pada kinerja karyawan masih rendah. Dimana karyawannya masih ada melanggar peraturan-peraturan yang telah di tetapkam pada Dinas Pekerjaan Umum Dan Penataan Ruang Provinsi Sumatera Barat. Barat. Pelanggaran yang di buat pada karyawan adalah, karyawan sering terlambat masuk kerja, Dan karyawan keluar masuk dalam jam kerja tanpa ada kepentingan pekerjaan begitu juga ada karyawan pulang kerja lebih cepat pada waktu yang telah di tetapkan.

Hal ini, Kondisi ini akan membuat karyawan berkerja kurang efektif dan akan memberikan dampak kurang baik terhadap kinerja karyawan pada Dinas Dinas 
Pekerjaan Umum Dan Penataan Ruang Provinsi Sumatera Barat.

\section{Hepotesis}

H1:Diduga

Kepemimpinan

berpengaruh positif dan signifikat terhadap kinerja karyawan.

H2: Diduga Motivai berpengaruh positif dan signifikat terhadap kinerja karyawan.

H3: Diduga Stres Keja berpengaruh positif dan signifikat terhadap kinerja karyawan.

\section{METODE PENELITIAN \\ Populasi Dan Sampel}

Populasi dalam penelitian ini adalah seluruh karyawan di Dinas Pekerjaan Umum Dan Penataan Ruang Provinsi Sumatera Barat yang berjumlah 423 orang.

Sampel adalah bagian dari jumlah dan karakteristik yang dimiliki populasi. Sampel ini menggunakan rumus Slovin.

Pada penelitian ini, jumlah sampel yang dipakai oleh peneliti sebanyak 81 responden, jumlah tersebut merupakan jumlah sampel diatas minimal agarterhindar dari sampel error.

\section{Jenis Dan Sumber Data}

Menurut Sugiyono (2015) data kuantitatif adalah metode penelitian yang berlandaskan pada filsafat posuitivisme, digunakan untuk meneliti pada populasi atau sampel tertentu, pengumpulan data mengunakan instrument penelitian. Sedangkan sumber data yang dipakai pada penelitian ini ialah data primer dan data sekunder. Data primer dalam penelitian ini diperoleh melalui pengisian kuesioner. Data Sekunder penlitian ini diperoleh melalui orang lain atau lewat dokumen.

\section{Definisi Operasional Variabel}

Operasional adalah "penentuan konstrak atau sifat yang akan dipelajari sehingga menjadi variabel yang dapat diukur".Definisi operasional menjelaskan cara tertentu yang digunakan untuk meneliti dan mengoperasikan konstrak, sehingga memungkinkan bagi peneliti yang lain untuk melakukan replikasi pengukuran dengan cara yang sama atau mengembangkan cara pengukuran konstrak yang lebih baik. Berdasarkan perumusan masalah, variabel dalam penelitian ini terdiri dari Kepemimpinan, Motivasi Dan Stres kerja Terhadap Kinerja Karyawan.

Kepemimpinan merupakan proses mempengaruhi atau memberi contoh oleh pemimpin kepada pengikutnya atau bawahannya dalam upaya mencapai tujuan organisasi (Parmin, 2016). Kepemimpinan dapat di ukur bebrapa indikator yaitu, Arahan, Supervisi, Kunsultasi, .Pendelegasian Wewenang.

Motivasi Joko Haryanto, (2016) adalah dorongan-dorongan yang timbul pada atau di dalam seorang individu yang menggerakkan dan mengarahkan perilaku. Motivasi dapat di ukur beberapa indikator yaitu, Tingkat Produktivitas. Tingkat Absensi, Tingkat Kualitas Hasil Kerja, Tingkat Penghasilan, Tingkat Penerimaan Kelompok, Promosi Jabatan.

Stres Kerja Astianto, (2014) adalah suatu kondisi ketegangan yang mempengaruhi emosi, proses berpikir dan kondisi seseorang. Dalam Stres Kerja dapat di ukur bebrapa indikator yaitu, Psikologis, Fisik, Prilaku.

Kinerja Karyawan Suatu kondisi yang harus diketahui dan di 
konfirmasikan kepada pihak tertentu untuk mengetahui tingkat pencapaian hasil individu dihubungkan dengan visi yang diemban suatu organisasi, serta mengetahui dampak positif dan negatif dari suatu kebijakan operasional (Hotiana, 2018). Dalam Kinerja Karyawan ada beberapa indikator, Jumlah pekerjaan yang dihasilkan individu, Kualitas hasil, Menyelesaikan pekerjaan dengan tepat waktu, Tingkat kehadiran bekerja secara tim.

\section{TEKNIK ANALISIS DATA Uji Validitas}

Uji validitas merupakan pengukuran ketepatan atau kevalidan dari suati instrument yang diukur dan suatualat ukur dapat dikatakan mempunyai validitas tinggi apabila dapat dijalankan fungsi ukurnya atau memberikan hasil ukur yang sesuai dengan maksud dan tujuan dari diadakannya tes atau penilaian tersebut.

Apabila nillai $\mathrm{r}$ hitung (nilai Corrected Item-Total Correlation) $\geq$ $\mathrm{r}$ tabel (uji 2 sisi dengan sig. 0,03) maka instrument atau item-item pertanyaan berkorelasi signifikan terhadap skor total (valid).

Apabiila nilai $r$ hitung (nilaiCorreected Item-Total Correlation) < r tabel (uji 2 sisi dengan sig. 0,03) maka instrumennt atau item-item pertanyaan tidak berkorelasi signifikan terhadap skor total (tidak valid).

\section{Uji Reliabilitas}

Uji reliabilitas adalah uji terhadap instrumenn yang bila digunakan beberapa kali untuk mengukur objek yang sama akan menghasilkan data yang sama (Sugiyono, 2015).

Uji reabilitas dapat dilakukan secara bersama-sama terhadap seluruh butir pernyataan untuk lebih dari satu variabel, namun sebaiknya uji reliabilitas sebaliknya dilakukan pada masing-masing variabel pada lembar kerja yang berbeda sehingga dapat diketahui konstruk variabel mana yang tidak reliabel. Reliabilitas suatu konstuk variabel dikatakan baik jika memiliki nilai Cronbach's Alpha $>0,06$. Sehingga pengambilan keputusan adalah:

1. Jika $r$ Alpha positif, serta $r>0,06$ maka dimensi tersebut reliabel.

2. Jika $r$ Alpha positif, serta $r \leq 0,06$ maka dimensi tersebut tidak reliabel.

\section{Analisis Deskriptif (Uji TCR)}

Menghitung nilai Tingkat Capaian Responden(TCR) masingmasing kategori dari data deskriptif variabel.

Rumus yang digunakan yaitu:

$$
\mathrm{TCR}=\mathrm{Rs} / \mathrm{n} * 100 \%
$$

Keterangan:

TCR $=$ Tingkat Capaian Responden

Rs = Rata-rata skor jawaban responden

$\mathrm{n} \quad=$ Nilai skor jawaban

Kriteria interpretasi skor untuk Tingkat Capaian Responden (TRC) dalam penelitian ini adalah:

Tabel 3.2

Rentang Skala TCR

\begin{tabular}{ccl}
\hline No & \multicolumn{1}{c}{ Angka } & \multicolumn{1}{c}{ Keterangan } \\
\hline 1. & $81 \%-100 \%$ & Sangat Setuju (SS) \\
\hline 2. & $61 \%-80 \%$ & Setuju (S) \\
\hline 3. & $41 \%-60 \%$ & Kurang Setuju (KS) \\
\hline 4. & $21 \%-40 \%$ & Tidak Setuju (TS) \\
\hline 5. & $00 \%-20 \%$ & $\begin{array}{l}\text { Sangat Tidak Setuju } \\
\text { (STS) }\end{array}$ \\
\hline \multicolumn{3}{c}{ UJI ASUMSI KLASIK } \\
Uji Normalitas
\end{tabular}

Kualitas data diuji dengan menggunakan uji normalitas. Pengujian normalitas data dilakukan dengan menggunaakan KolmogorofSmirnov. Pengujian ini dilakukan untuk mengetahui distribusi data. 
Jika nilai signifikansi lebih besar dari 0,05 maka data terdistribusi dengan normal, dan jika kurang dari 0,05 maka data terdistribusi dengan tidak normal.

\section{Uji Multikonearitas}

Uji multikolinearitas

digunakan untuk mengetahui ada atau tidaknya penyimpangan asumsi klasik yaitu adanya hubungan linear antara variabel independen dalam model regresi (Hotiana, 2018). Untuk membuktikan hipotesis tersebut ada beberapa statistik yang sering digunakan untuk menguji variabel-variabel bebas tersebut, Suatu model regresi dikatakan bebas dari masalah multikolinearits jika mempunyai nilai tolerance value > 0,10 atau VIF $<10$.

\section{Uji Heteroskedastisitas}

Uji Heteroskedastisitas bertujuan untuk menguji apakah dalam model regresi terjadi ketidaksamaan varian dari residual satu pengamatan ke pengamatan yang lain. Jika varian dari residual satu pengamatan ke pengamatan lain tetap, maka disebut homoskedastisitas. Model regresi yang baik adalah homoskedastisitas atau tidak terjadi heteroskedastisitas (Joko Haryanto, 2016).

\section{Uji Autokorelasi}

Uji Autokorelasi dilakukan untuk mengetahui ada tidaknya korelasi antara variabel pada periode tertentu dengan variabel sebelumnya. Autokorelasi muncul karena oservasi yang berurutan sepanjang waktu berkaitan satu sama lainnya.

\section{Analisis Regresi Berganda}

Analisis regresi linier berganda bermaksud meramalkan bagaimana keadaan (naik turunnya) variabel dependen, bila dua atau lebih variabel independen sebagai faktor prediktor dimanipulasi (dinaik turunkan nilainya). Jadi analisis regresi berganda akan dilakukan bila jumlah variabel independennya minimal 2 (Sugiyono, 2013).

$$
\begin{aligned}
& \mathrm{Y}=\alpha+\beta 1 \mathrm{X} 1+\beta 2 \mathrm{X} 2+\beta 3 \mathrm{X} 3+\mathrm{e} \\
\mathrm{Y}= & \text { Kinerja karyawan } \\
\mathrm{X} 1= & \text { Kepemimpinan } \\
\mathrm{X} 2= & \text { Motivasi } \\
\mathrm{X} 3= & \text { Stres Kerja } \\
\alpha= & \text { Konstanta } \\
\beta 1= & \text { Koefisien regresi untuk } \\
& \text { kepemimpinan } \\
\beta 2= & \text { Koefisien regresi untuk } \\
& \text { Motivasi } \\
\beta 3= & \text { Koefisien regresi untuk Stres } \\
& \text { Kerja } \\
\mathrm{e}= & \text { Standar error }
\end{aligned}
$$

\section{Koefisien Determinasi}

Variabel bebas secara bersamasama terhadap variabel terikatnya dengan melihat besarnya koefisien determinasi totalnya $\left(\mathrm{R}^{2}\right)$. Jika $\left(\mathrm{R}^{2}\right)$ yang diperoleh mendekati 1 (satu) maka dapat dikatakan semakin kuat model tersebut menerangkan hubungan variabel bebas terhadap variabel terikat. Sebaliknya jika $\left(\mathrm{R}^{2}\right)$ makin mendekati 0 (nol) maka semakin lemah pengaruh variabelvariabel bebas terhadap variabel terikat.

\section{Hipotesis}

\section{T-Test (Uji t statistik)}

Uji $\mathrm{T}$ digunakan untuk mengetahui apakah masing-masing variabel bebasnya secara sendirisendiri berpengaruh secara signifikan terhadap variabel terikatnya.Dimana $\mathrm{T}$ tabel $>\mathrm{T}$ hitung, $\mathrm{H}_{0}$ diterima. Dan jika $\mathrm{T}$ tabel < Thitung, maka $\mathrm{H}_{\mathrm{a}}$ diterima, begitupun jika sig $>\alpha$ $(0,05)$, maka $\mathrm{H}_{0}$ diterima $\mathrm{H}_{\mathrm{a}}$ ditolak dan jika sig $<\alpha$ ́ $(0,05)$, maka $\mathrm{H}_{0}$ ditolak $\mathrm{H}_{\mathrm{a}}$ diterima. 
HASIL PENELITIAN DAN PEMBAHASAN

\section{Karakteristik Responden}

Deskripsi statistik responden menjelaskan mengenai frekuensi dan persentase responden berdasarkan jenis kelamin, umur, pendidikan dan lama kerja pada karyawan.

Tabel 4.1

Karakteristik Responden Berdasarkan Jenis Kelamin

\begin{tabular}{ccc}
\hline $\begin{array}{c}\text { Jenis } \\
\text { Kelamin }\end{array}$ & $\begin{array}{c}\text { Frekuensi } \\
\text { (Orang) }\end{array}$ & Persentase \\
\hline Laki-Laki & 60 & 74,1 \\
\hline Perempuan & 21 & 25,9 \\
\hline Total & 81 & 100 \\
\hline
\end{tabular}

Sumber: Hasil Analisis Data Penelitian Th.2018

Tabel diatas menjelaskan bahwa komposisi jenis kelamin responden, dimana 60 orang $(74,1 \%)$ responden adalah laki-laki dan sebanyak 21 orang $(25,9 \%)$ adalah perempuan. Jadi dapat disimpulkan jenis kelamin laki-laki paling banyak pada penelitian ini.

Tabel 4.2

Karakteristik Responsden Berdasarkan Umur

\begin{tabular}{ccc}
\hline Umur & $\begin{array}{c}\text { Frekuensi } \\
\text { (Orang) }\end{array}$ & Persentase \\
\hline 20-30 Tahun & 18 & 22,2 \\
\hline 31-40 Tahun & 51 & 63 \\
\hline$>$ 45 Tahun & 12 & 14,8 \\
\hline Total & 81 & $100 \%$ \\
\hline Sumber:
\end{tabular}

Sumber: Hasil Analisis Data Penelitian Th. 2018

Tabel diatas menjelaskan bahwa komposisi umur responden, dimana 18 orang $(22,2 \%)$ responden dengan umur 20-30 tahun, sebanyak 51 orang (63\%) dengan umur 31-40 tahun dan sebanyak 12 orang $(14,8 \%)$ responden dengan umur > 45 tahun . Jadi dapat disimpulkan umur responden paling banyak adalah 31-40 tahun.
Tabel 4.3

Karakteristik Responden Berdasarkan Pendidikan Terakhir

\begin{tabular}{|c|c|c|}
\hline $\begin{array}{c}\text { Pendidikan } \\
\text { Terakhir }\end{array}$ & $\begin{array}{c}\text { Frekuensi } \\
\text { (Orang) }\end{array}$ & $\begin{array}{c}\text { Persentase } \\
(\%)\end{array}$ \\
\hline D3 & 19 & 23,5 \\
\hline S1 & 60 & 74,1 \\
\hline S2 & 2 & 2,5 \\
\hline Total & 81 & 100 \\
\hline
\end{tabular}

Tabel diatas menjelaskan bahwa pendidikan terakhir D3 sebanyak 19 orang $(23,5 \%), \mathrm{S} 1$ sebanyak 60 orang $(74,1)$ dan pendidikan S2 sebanyak 2 orang $(2,5 \%)$. Jadi dapat disimpulkan bahwa karyawan paling banyak dengan pendidikan S1.

Tabel 4.4

Karakteristik Responden

Berdasarkan Lama Bekerja

\begin{tabular}{ccc}
\hline $\begin{array}{c}\text { Pendidikan } \\
\text { Terakhir }\end{array}$ & $\begin{array}{c}\text { Frekuensi } \\
\text { (Orang) }\end{array}$ & $\begin{array}{c}\text { Persentase } \\
(\mathbf{\%})\end{array}$ \\
\hline 5-10 tahun & 74 & 91,4 \\
\hline 10-20 tahun & 7 & 8,6 \\
\hline Total & 81 & 100 \\
\hline
\end{tabular}

Sumber: Hasil Analisis Data Penelitian Th.2018

Tabel diatas menjelaskan bahwa sebanyak 74 orang $(91,4 \%)$ dengan lama bekerja 5-10 tahun dan sebanyak 7 orang $(8,6 \%)$ dengan lama bekerja 10-20 tahun. Jadi dapat disimpulkan bahwa karyawan paling banyak dengan 1 ama bekerja 5-10 tahun. 
Hasil Analisis PENELITIAN

Uji Validitas

1. Kepemimpinan (X1)

Tabel 4.5

Hasil Uji Validitas Kepeminpinan (X1)

\begin{tabular}{cccc}
\hline Variabel & $\begin{array}{c}\text { Corrected } \\
\text { Item-Total } \\
\text { Correlation }\end{array}$ & Batas & Kilai \\
& & \\
\hline
\end{tabular}

motivasi yang dirancang dengan 12 item pernyataan, secara keseluruhan semua item pertanyaan sudah bernilai valid, hal ini ditunjukan oleh nilai corrected item total correlation $>0,300$.

3. Stres Kerja (X3)

Tabel 4.7

Hasil Uji Validitas Stres kerja

\begin{tabular}{|c|c|c|c|c|c|c|c|}
\hline 1 & 0.529 & 0.300 & Valid & Variabel & Corrected & Batas & Keterangan \\
\hline 2 & 0.791 & 0.300 & Valid & & Item-Total & Nilai & \\
\hline 3 & 0.576 & 0.300 & Valid & & Correlation & & \\
\hline 4 & 0.867 & 0.300 & Valid & 1 & 0.459 & 0.300 & Valid \\
\hline 5 & 0.600 & 0.300 & Valid & 2 & 0.643 & 0.300 & Valid \\
\hline 6 & 0.581 & 0.300 & Valid & 3 & 0.502 & 0.300 & Valid \\
\hline 7 & 0.819 & 0.300 & Valid & 4 & 0.646 & 0.300 & Valid \\
\hline 8 & 0.603 & 0.300 & Valid & 5 & 0.595 & 0.300 & Valid \\
\hline Sumber: & Data Primer & diolah & gatn & $\frac{6}{7}$ & 0.643 & 0.300 & Valid \\
\hline & SPSS Th.2018 & & & 7 & 0.544 & 0.300 & Valid \\
\hline & erdasarkan & tta $\mathrm{Ta}$ & 4 4 & 8 & 0.573 & 0.300 & Valid \\
\hline
\end{tabular}

hasil pengujian validitas variabel kepemimpinan yang dirancang dengan 8 item pernyataan, secara keseluruhan 8 item pertanyaan sudah bernilai valid, hal ini ditunjukan oleh nilai corrected item total correlation $>0,300$.

\section{Motivasi (X2)}

Tabel 4.6

Hasil Uji Validitas motivasi (X2)

\begin{tabular}{|c|c|c|c|c|c|c|}
\hline \multirow{2}{*}{$\begin{array}{c}\text { Variabel } \\
1\end{array}$} & \multirow{2}{*}{$\begin{array}{c}\begin{array}{c}\text { Corrected } \\
\text { Item-Total } \\
\text { Correlation }\end{array} \\
0.835\end{array}$} & \multirow{2}{*}{$\begin{array}{c}\begin{array}{c}\text { Batas } \\
\text { Nilai }\end{array} \\
0.300\end{array}$} & \multicolumn{4}{|c|}{$\begin{array}{c}\text { Keterangan. Kinerja Karyawan }(Y) \\
\text { Tabel } 4.8 \\
\text { Hasil Uji Validitas Kinerja Karyawan } \\
\end{array}$} \\
\hline & & & Varifibel & \multirow{3}{*}{$\begin{array}{c}\text { Corrected } \\
\text { Item-Total } \\
\text { Correlation }\end{array}$} & \multirow{3}{*}{$\begin{array}{l}\text { Batas } \\
\text { Nilai }\end{array}$} & \multirow[t]{3}{*}{ Keterangan } \\
\hline 2 & 0.841 & 0.300 & Valid & & & \\
\hline 3 & 0.691 & 0.300 & Valid & & & \\
\hline 4 & 0.543 & 0.300 & Valitd & 0.713 & 0.300 & Valid \\
\hline 5 & 0.518 & 0.300 & Valifd & 0.723 & 0.300 & Valid \\
\hline 6 & 0.864 & 0.300 & Valisd & 0.520 & 0.300 & Valid \\
\hline 7 & 0.727 & 0.300 & Valitd & 0.411 & 0.300 & Valid \\
\hline 8 & 0.604 & 0.300 & Valisd & 0.580 & 0.300 & Valid \\
\hline 9 & 0.767 & 0.300 & Valfd & 0.752 & 0.300 & Valid \\
\hline 10 & 0.833 & 0.300 & Validd & 0.736 & 0.300 & Valid \\
\hline 11 & 0.623 & 0.300 & Valsd & 0.616 & 0.300 & Valid \\
\hline 12 & 0.864 & 0,300 & Vallid & nber: Data & imer d & lah dengan \\
\hline $\begin{array}{r}\text { Imber: } \\
S \\
\text { Ber } \\
\text { sil per }\end{array}$ & $\begin{array}{l}\text { Primer } \\
\text { Th.2018 } \\
\text { kan data } \\
\text { an valid }\end{array}$ & Tabel. & & $\begin{array}{l}\text { Berdasark } \\
\text { il pengujia } \\
\text { erja karyau } \\
\text { gan } 8 \text { item }\end{array}$ & $\begin{array}{r}\text { n data } \\
\text { validi } \\
n \text { yan } \\
\text { pernya }\end{array}$ & $\begin{array}{r}\text { Tabel } 4.8 \\
\text { as variabel } \\
\text { dirancang } \\
\text { aan, secara }\end{array}$ \\
\hline
\end{tabular}

\section{SPSS Th.2018}

Berdasarkan data Tabel 4.7 hasil pengujian validitas variabel stres kerja yang dirancang dengan 8 item pernyataan, secara keseluruhan semua item pertanyaan sudah bernilai valid, hal ini ditunjukan oleh nilai corrected item total correlation $>0,300$. 
keseluruhan semua item pertanyaan sudah bernilai valid, hal ini ditunjukan oleh nilai corrected item total correlation $>0,300$.

\section{Uji Reliabilitas}

Uji Reliabilitas bertujuan untuk responden dapat memberikan hasil yang relative tidak berbeda (konsisten) bila dilakukan pengukuran ulang terhadap subjek yang sama. Pengujian reliabilitas dilakukan dengan pendekatan Cronbach's Alpha. Instrument yang handal (reliable) apabila memiliki Cronbach's Alpha lebih dari 0,60.

Tabel 4.9

Hasil Uji Reliabilitas menilai sejauh mana jawaban dari

Berdasarkan hasil analisis yang telah dilakukan dari 8 item pernyataan mengenai kepemimpinan yang memiliki skor rata-rata tertinggi adalah pernyataan nomor delapan dengan nilai Rata-Rata 3,95 dengan Tingkat Capaian Responden 79,01\%, Sedangkan nilai Rata-Rata Terendah adalah pertanyaan nomor empat dengan nilai Rata-Rata 3,68 dengan Tingkat Capaian Responden 73,58\%, dimana hasilnya setuju.

\section{Motivasi}

Berdasarkan hasil pengujian menemukan bahwa total skor dari variabel motivasi memiliki nilai TCR sebesar $77,90 \%$ dengan Rata-Rata 3.90 dimana nilai tersebut termasuk

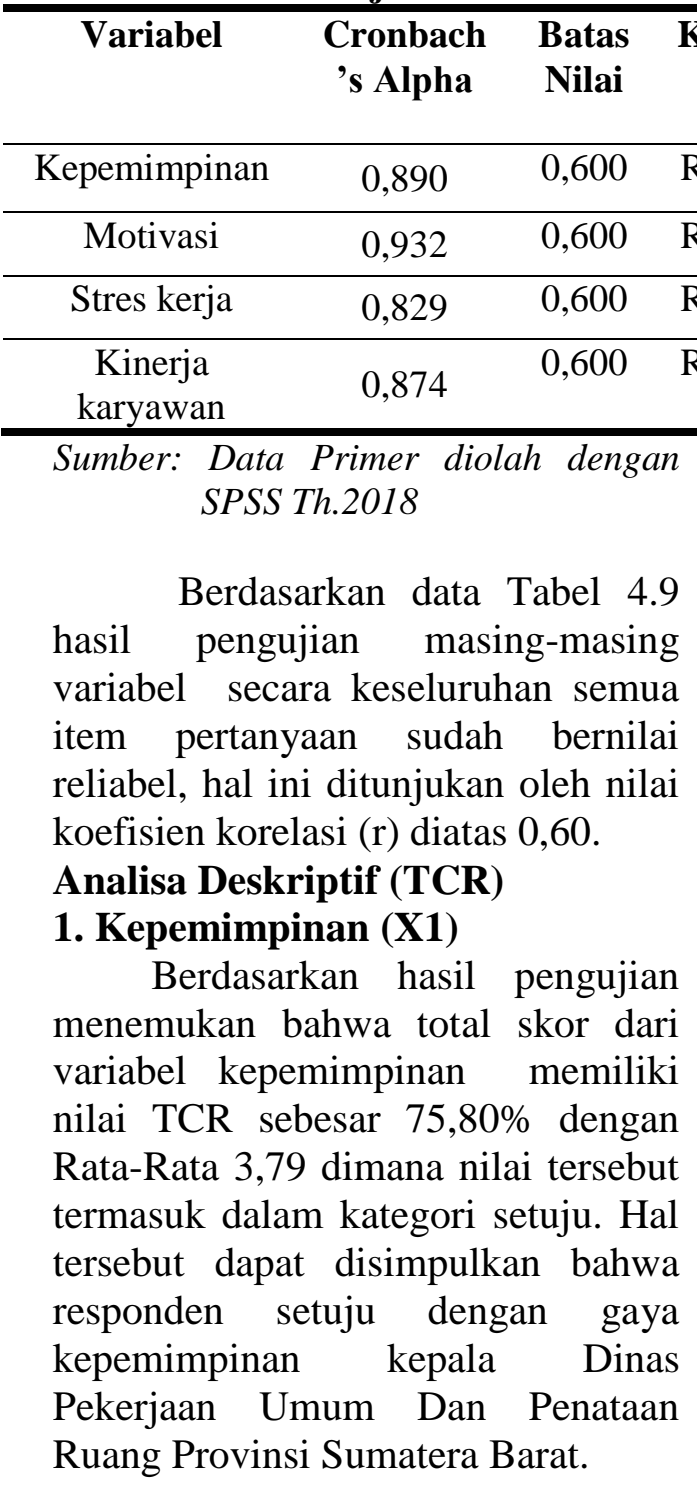


dengan nilai Rata-Rata 3,95 dengan Tingkat Capaian Responden 79,01, Sedangkan nilai Rata-Rata Terendah adalah pertanyaan nomor enam dengan nilai Rata-Rata 3,54 dengan Tingkat Capaian Responden 70,86\%, dimana hasilnya setuju.

\section{Kinerja Karyawan}

Berdasarkan

pengujian menemukan bahwa total skor dari variabel kinerja karyawan memiliki nilai TCR sebesar $72,96 \%$ dengan Rata-Rata 3,65 dimana nilai tersebut termasuk dalam kategori setuju. Hal tersebut dapat disimpulkan bahwa responden setuju dengan penilaian kinerja karyawan.

Berdasarkan hasil analisis yang telah dilakukan dari 8 item pernyataan mengenai kinerja karyawan yang memiliki skor ratarata tertinggi adalah pernyataan nomor tiga dengan nilai Rata-Rata 4,09 dengan Tingkat Capaian Responden $81,73 \%$, Sedangkan nilai Rata-Rata Terendah adalah pertanyaan nomor lima dengan nilai Rata-Rata 3,22 dengan Tingkat Capaian Responden 64,44\%, dimana hasilnya setuju.

\section{Uji Asumsi Klasik}

\section{Uji Normalitas}

Uji Normalitas bertujuan untuk menguji apakah dalam suatu model regresi mempunyai distribusi yang normal. Dalam penelitian ini digunakan uji One Sample Kolmogorov-Smirnov. Uji One Sample Kolmogorov-Smirnov dasar keputusannya adalah berdasarkan probabilitas (asymptotic significance), yaitu jika pvalue > 0,05 maka dapat disimpulkan data tersebut bernilai normal.

Berdasarkan hasil pengolahan data terlihat bahwa nilai asymp.sig > 0,05 untuk semua variabel. Maka dapat disimpulkan bahwa hasil uji normalitas kolmogrov-smirnov data tersebut terdistribusi normal karena nilai signifikan lebih besar dari 0,05 .

\section{Uji Multikolinearitas}

Uji multikolinieritas bertujuan untuk menguji apakah model regresi yang ditemukan adanya korelasi antar variabel bebas. Model regresi yang baik adalah tidak terjadi gejala multikoliniaritas (Ghozali, 2001) Kriteria uji multikolinearitas yaitu apabila Tolerance < 0,10 dan VIF > 10 Maka ada Multikolinearitas.

Berdasarkan hasil pengolahan data dapat dilihat bahwa masingmasing variabel independen memiliki nilai tolerance $>0.1$, dan masing-masing variabel independent VIF < 10 berdasarkan hasil pengolahan data diatas maka dapat disimpulkan bahwa penelitian ini terbebas dari masalah Multikolinearitas.

\section{Uji Heteroskedastisitas}

Uji Heteroskedastisitas digunakan menguji apakah dalam model regresi terjadi ketidaksamaan variance dari residual satu pengamatan ke pengamatan yang lain. Penelitian ini menggunakan dua metode uji heteroskedastisitas yaitu dengan model uji glejser. Untuk model uji glejser jika probabilitas > 0,05 berarti tidak terjadi heteroskedastisitas. Metode garis plot apabila plot menyebar dan tidak membentuk suatu pola maka tidak terjadi masalah heteroskedastisitas.

Berdasarkan hasil uji heteroskedastisitas diatas dapat diketahui bahwa nilai signifikan variabel kepemimpinan, motivasi dan stres kerja nilai semuanya > 0,05. Jadi dapat disimpulkan bahwa semua nilai variabel terbebas dari gejala heteroskedastisitas. 
Berdasarkan hasil, maka dapat dirumuskan persamaan regresi linear berganda sebagai berikut:

$\mathrm{Y}=\mathrm{a}+\mathrm{b}_{1} \mathrm{X}_{1}+\mathrm{b}_{2} \mathrm{X}_{2}+\mathrm{b}_{3} \mathrm{X}_{+} \mathrm{e}$

$\mathrm{Y}=19,162+0,183 \mathrm{X}_{1}+0,170 \mathrm{X}_{2}-0,115 \mathrm{X}_{3}+\mathrm{e}$

1. Dari model persamaan regresi linear berganda di atas dapat diketahui bahwa nilai konstanta sebesar 19,162 yang berarti bahwa tanpa adanya pengaruh dari variable kepemimpinan, motivasi dan stres jerha maka kinerja karyawan sudah mencapai 19,162 satuan.

2. Koefisien regresi variabel kepemimpinan $\left(\mathrm{X}_{1}\right)$ sebesar 0,183 . Hal ini berarti apabila kepemimpinan meningkat sebesar satu satuan maka kinerja karyawan akan meningkat sebesar 0,183 dalam setiap satuannya. Dengan asumsi variabel lain tidak mengalami perubahan atau konstan.

3. Koefisien regresi variabel motivasi $\left(\mathrm{X}_{2}\right)$ sebesar 0,170 . Hal ini berarti apabila motivasi meningkat sebesar satu satuan maka kinerja karyawan akan meningkat sebesar 0,170 dalam setiap satuannya. Dengan asumsi variabel lain tidak mengalami perubahan atau konstan.

4. Koefisien regresi variabel stres $\operatorname{kerja}\left(\mathrm{X}_{3}\right)$ sebesar $-0,115$. Hal ini berarti apabila stres kerja menurun sebesar satu satuan maka kinerja karyawan akan meningkat sebesar 0,115 dalam setiap satuannya. Dengan asumsi variabel lain tidak mengalami perubahan atau konstan.

Koefisien Determinasi $\mathbf{R}^{2}$

Koefisien determinasi bertujuan untuk mengukur seberapa jauh kemampuan model dalam menerangkan variasi variabel dependen.
Berdasarkan tabel 4.19 diatas dapat terlihat bahwa besarnya nilai $\mathrm{R}$ Square (dilihat dari Adjusted $\mathrm{R}$ square) sebesar 0,399. Hal ini berarti 39,9\% kinerja karyawan dipengaruhi oleh kepemimpinan, motivasi dan stres kerja sedangkan sisanya $60,1 \%$ disebabkan oleh hal-hal lain yang ada diluar penelitian seperti lingkungan kerja dan Budaya Organisasi.

\section{Uji Hipotesis (Uji T)}

Berdasarkan hasil pengolahan uji t parsial, maka dapat disimpulkan bahwa:

1. Terlihat bahwa kepemimpinan memiliki nilai koefisien regresi positif dengan nilai $t$ hitung sebesar 3,325 dengan nilai sig sebesar 0,001. Jika dibandingkan dengan ( $\mathrm{t}$ tabel, sig 0.05, df (81-2) =79. Maka dapat terlihat bahwa dengan nilai $\mathrm{t}$ hitung 3,325> $\mathrm{t}$ tabel 1,990 , dan nilai sig $0,001<$ 0.05 , maka dapat disimpulkan bahwa Ha diterima dan Ho ditolak artinya bahwa kepemimpinan berpengaruh positif dan signifikan terhadap kinerja karyawan karyawan.

2. Terlihat bahwa motivasi memiliki nilai koefisien regresi positif dengan nilai $t$ hitung sebesar 4,275 dengan nilai sig sebesar 0,000. Jika dibandingkan dengan ( $\mathrm{t}$ tabel, sig 0.05, df (81-2) = 79). Maka dapat terlihat bahwa dengan nilai $\mathrm{t}$ hitung 4,275, > $\mathrm{t}$ tabel 1,990 , dan nilai sig $0,000<0.05$, maka dapat disimpulkan bahwa Ha diterima dan Ho ditolak artinya bahwa motivasi berpengaruh positif dan signifikan terhadap keputusan kinerja karyawan.

3. Terlihat bahwa stres kerja memiliki nilai koefisien regresi negatif dengan nilai $t$ hitung 
sebesar 2,278 dengan nilai sig sebesar 0,025. Jika dibandingkan dengan (t tabel, sig 0.05, df (81-2) =79). Maka dapat terlihat bahwa dengan nilai $\mathrm{t}$ hitung 2,278, > $\mathrm{t}$ tabel 1,990, dan nilai sig $0,025<$ 0.05, maka dapat disimpulkan bahwa $\mathrm{Ha}$ diterima dan $\mathrm{Ho}$ ditolak artinya bahwa stres kerjai berpengaruh negatif dan signifikan terhadap kinerja karyawan.

\section{PEMBAHASAN}

1. Pengujian Kepemimpinan Terhadap Kinerja Karyawan Pada Dinas Pekerjaan Umum Penataan Ruang Provinsi Sumatera Barat.

Berdasarkan penelitian diperoleh hasil kepemimpinan memiliki nilai koefisien regresi positif dengan nilai $t$ hitung sebesar 3,325 dengan nilai sig sebesar 0,001. Jika dibandingkan dengan (t tabel, sig 0.05, df (81-2) $=79$. Maka dapat terlihat bahwa dengan nilai $\mathrm{t}$ hitung $3,325>\mathrm{t}$ tabel 1,990, dan nilai sig 0,001 < 0.05 , maka dapat disimpulkan bahwa Ha diterima dan Ho ditolak artinya bahwa kepemimpinan berpengaruh positif dan signifikan terhadap kinerja karyawan.

H1: Diduga Kepemimpinan berpengaruh positif dan signifikat terhadap Kinerja Karyawan.

2. Pengujian Motivasi Terhadap Kinerja Karyawan Pada Dinas Pekerjaan Umum Penataan Ruang Provinsi Sumatera Barat.

Berdasarkan penelitian diperoleh hasil motivasi memiliki nilai koefisien regresi positif dengan nilai $t$ hitung sebesar 4,275 dengan nilai sig sebesar
0,000. Jika dibandingkan dengan ( $\mathrm{t}$ tabel, sig 0.05, df $(81-2)=79)$. Maka dapat terlihat bahwa dengan nilai $\mathrm{t}$ hitung 4,275, > $\mathrm{t}$ tabel 1,990 , dan nilai sig $0,000<0.05$, maka dapat disimpulkan bahwa $\mathrm{Ha}$ diterima dan Ho ditolak artinya bahwa motivasi berpengaruh positif dan signifikan terhadap kinerja karyawan.

H2: Diduga Motivasi berpengaruh positif dan signifikat terhadap Kinerja Karyawan.

3. Pengujian Stres Kerja Terhadap Kinerja Karyawan Pada Dinas Pekerjaan Umum Penataan Ruang Provinsi Sumatera Barat.

Berdasarkan penelitian diperoleh hasil stres kerja memiliki nilai koefisien regresi negatif dengan nilai $\mathrm{t}$ hitung sebesar 2,278 dengan nilai sig sebesar 0,025. Jika dibandingkan dengan ( $\mathrm{t}$ tabel, sig 0.05, df (81-2) =79). Maka dapat terlihat bahwa dengan nilai $\mathrm{t}$ hitung 2,278, > $\mathrm{t}$ tabel 1,990, dan nilai sig $0,025<$ 0.05, maka dapat disimpulkan bahwa Ha diterima dan Ho ditolak artinya bahwa stres kerjai berpengaruh negatif dan signifikan terhadap kinerja karyawan.

H3: Diduga Stres Kerja berpengaruh positif dan signifikat terhadap Kinerja Karyawan.

\section{KESIMPULAN}

Berdasarkan hasil pengujian dan pembahasan mengenai Pengaruh kepemimpinan, motivasi dan stres kerja terhadap kinerja karyawan pada Dinas Pekerjaan Umum Penataan Ruang Provinsi Sumatera Barat, maka dapat ditarik kesimpulan, antara lain: 
1. Kepemimpinan memiliki nilai koefisien regresi positif dengan nilai $\mathrm{t}$ hitung sebesar 3,325 dengan nilai sig sebesar 0,001 . Jika dibandingkan dengan ( $\mathrm{t}$ tabel, sig 0.05, df (81-2) = 79. Maka dapat terlihat bahwa dengan nilai $t$ hitung 3,325> t tabel 1,990, dan nilai sig $0,001<0.05$, maka dapat disimpulkan bahwa Ha diterima dan Ho ditolak artinya bahwa kepemimpinan berpengaruh positif dan signifikan terhadap kinerja karyawan.

2. Motivasi memiliki nilai koefisien regresi positif dengan nilai $t$ hitung sebesar 4,275 dengan nilai sig sebesar 0,000. Jika dibandingkan dengan (t tabel, sig 0.05 , df $(81-2)=79)$. Maka dapat terlihat bahwa dengan nilai $\mathrm{t}$ hitung 4,275, > t tabel 1,990, dan nilai sig $0,000<0.05$, maka dapat disimpulkan bahwa Ha diterima dan Ho ditolak artinya bahwa motivasi berpengaruh positif dan signifikan terhadap kinerja karyawan.

3. Stres kerja memiliki nilai koefisien regresi negatif dengan nilait hitung sebesar 2,278 dengan nilai sig sebesar 0,025. Jika dibandingkan dengan ( $\mathrm{t}$ tabel, sig 0.05, df (81-2) = 79). Maka dapat terlihat bahwa dengan nilai $\mathrm{t}$ hitung 2,278, > t tabel 1,990, dan nilai sig $0,025<0.05$, maka dapat disimpulkan bahwa Ha diterima dan Ho ditolak artinya bahwa stres kerjai berpengaruh negatif dan signifikan terhadap kinerja karyawan.

\section{UCAPAN TERIMA KASIH}

Selesainya penulisan ini, karena penulis banyak menerima masukan dan dorongan baik motivasi secara moral atau spiritual. Oleh karena itu penulis ingin mengucapkan terimakasih kepada:

1. Bapak Febryandhie Ananda, SE, Msi. selaku ketua STIE"KBP" Padang

2. Ibu Febsri Susanti, SEI, MM. selaku ketua Program Studi Manajemen

3. Ibu Maria Magdalena, S.pd,MM sebagai dosen pembimbing dalam pembuatan skripsi ini dan penulis banyak berterima kasih atas kesabaran, kepedulian dan kesempatan yang sudah diberikan, penulis berharap kebaikan ibu bisa dibalas oleh Tuhan Yang Maha Esa

4. Ibu Maria Magdalena, S.Pd,MM sebagai penasehat akademik program studi manajemen

5. Seluruh bagian yang sudah banyak menolong penulis yang tidak dapat penulis sampaikan satu persatu.

\section{DAFTAR PUSTAKA}

Astianto, A. (2014). Pengaruh Stres Kerja Dan Beban Kerja Terhadap Kinerja Karyawan Pdam Surabaya. Jurnal Ilmu \& Riset Manajemen, 3(7).

Aldi, Y., \& Susanti, F. (2019). Pengaruh Stress Kerja Dan Motivasi Kerja Terhadap Prestasi Kerja Karyawan Pada PT. Frisian Flag Indonesia Wilayah Padang. https://doi.org/10.31227/osf.io/e $\mathrm{t} 4 \mathrm{rn}$

Dona, E. (2016). Pengaruh Perencanaan, Prosedur Dan Pengawasan dan Komitmen Organisasi Dalam Pelaksanaan Anggaran Terhadap Kinerja Pegawai Dinas Pekerjaan Umum Kota Pariaman. Jurnal Riset Manajemen dan 
Akuntansi (Jurmak), 23-35.

Hotiana, N. (2018). Pengaruh Motivasi Dan Stres Kerja Terhadap Kinerja Pegawai (Studi Pada Bagian Kepegawaian Dan Organisasi, Biro Umum, Kepegawaian Dan Organisasi Kementerian Pariwisata Ri). Jurnal Riset Manajemen Dan Bisnis (Jrmb), 3(1), 27-36.

Joko Haryanto. (2016). Pengaruh Kepemimpinan, Motivasi, Dan Disiplin Kerja, Terhadap Kinerja Dosen (Studi Pada Akademi Kesejahteraan Sosial Aks Ibu Kartini Semarang. Jurnal Stie Semarang, 8(1), 118.

Junaidi, R., \& Susanti, F. (2019). Pengaruh Gaya Kepemimpinan Dan Budaya Organisasi Terhadap Kinerja Pegawai Pada UPTD Baltekkomdik Dinas Pendidikan Provinsi Sumatera Barat.

https://doi.org/10.31227/osf.io/b zq75

Lubis, A. Y. O., \& Susanti, F. (2019). Pengaruh Gaya Kepemimpinan Dan

Kompensasi Terhadap Prestasi Kerja Karyawan (Studi pada PT Japfa Comfeed Indonesia (JCI) Tbk Devisi Fam 1. https://doi.org/10.31227/osf.io/7 tbrg

Marlius, D. RD Putra. (2018). Strategi Pengembangan Sulam Bayang. Jurnal Benefita: Ekonomi Pembangunan Manajemen Bisnis Dan Akuntansi. Volume 3. No. 2. Hal. 204-218. http://doi.org/10.22216/jbe.v3i2
.3494

Mayliza, R. (2019). Pengaruh Gaya Kepemimpinan Dan Disiplin Kerja Terhadap Kinerja Karyawan Dengan Motivasi Kerja Sebagai Variabel Intervening Pada PT. Semen Padang. https://doi.org/10.17605/OSF.I O/FYPQ9.

Mayliza, R. (2019). Pengaruh Konflik Dan Kejenuhan Terhadap Kepuasan Kerja Karyawan PT. PLN (Persero) Sektor Pembangkitan Dan Pengendalian Pembangkitan Ombilin.

https://doi.org/10.17605/OSF.I O/DQZ3K

Mayliza, R. (2019). Pengaruh Gaya Kepemimpinan Dan Disiplin Kerja Terhadap Kinerja Pegawai, Dengan Motivasi Kerja Sebagai Variabel Intervening (Studi Pada Dinas Pendidikan Kabupaten Tanah Datar).

https://doi.org/10.17605/OSF.I O/JGPDN

Nardo, R. Evanita, Syahrizal, S. (2018).

Pengaruh

Kepemimpinan

Transformasional, Dan Lingkungan Kerja Non Fisik Terhadap Perilaku Inovatif. JEBI (Jurnal Ekonomi dan Bisnis Islam) 3 (2), 209-215

Nardo, R. Evanita, Syahrizal, S. (2019). The Effect of Transformational Leadership and Non Physical Work Environment on Innovative Behavior with Work 
Motivation as a Mediation For Employees of Tour And Travel Companies In West Sumatera. 2nd Padang International Conference on Education, Economics, Business and Accounting (PICEEBA-2 2018)

Susriyanti, S. Nardo, R. (2019). Pengaruh Fungsi Komunikasi Dan Kepuasan Kerja Karyawan Terhadap Pemberian Pelayanan Nasabah PT. BPR LPN Talawi Sakato. Jurnal Administrasi Sosial dan Humaniora 3 (2), 97-111.

Putra, RY. Marlius, D. (2019). Pengaruh Pendidikan, Pengalaman Kerja dan Etos Kerja Terhadap Kinerja Pegawai Di KPN Batur. Academic Conference For Management 2.

Samosir, F., \& Magdalena, M. (2019). Effect Of Work Stress And Work Satisfaction Of Employees Performance Pt. Primatama Mulia Jaya Iv Koto Kinali Kecamatan Kinali Kab. Pasaman Barat. Https://Doi.Org/10.31219/Osf.I o/Gjvry

Utami, R. S., \& Magdalena, M. (2020, March 23). Pengaruh Kebutuhan Aktualisasi Diri Dan Beban Kerja Terhadap Prestasi Kerja Karyawan Pada Dinas Perindustrian dan Perdagangan Sumatera Barat. Retrieved from osf.io/kdyca

F., \& Magdalena, M. (2019). Pengaruh Komunikasi Lisan Dari Dokter Hewan Terhadap
Kepuasan Pelanggan Pada Produk Obat Di Pt Sanbe Farma Cabang Padang. Https://Doi.Org/10.31219/Osf.I o/Rgs5

Fatra, O., \& Magdalena, M. (2020, March 23). Pengaruh Pengembangan Karier, Penempatan Jabatan dan Motivasi Terhadap Prestasi Kerja Pegawai Pada Kantor Camat Kubung. https://doi.org/10.31219/osf.io/t s94j

Parmin. (2016). Analisis Pengaruh Kepemimpinan, Motivasi Dan Stres Kerja Terhadap Kinerja Karyawan Cv. Dian Prima Kebumen Parmin Abstrak. Jurnal Fokus Bisnis, 15(2), 102-126.

Prabowo, L. (N.D.). Pengaruh Lingkungan Kerja, Motivasi Kerja Dan Stres Kerja Terhadap Kinerja Pegawai. Jurnal Peneitian Ekonomi, 8, 24-31.

Ridho, M., \& Susanti, F. (2019). Pengaruh Stres Kerja Dan Motivasi Kerja Terhadap Kepuasan Kerja Pada Karyawan Bank Mandiri Syariah Cabang Padang. https://doi.org/10.31227/osf.io/p a2cg

Sugiyono. (2015). $\quad$ Statistik Nonparametriks Untuk Penelitian. Bandung: Alfabeta.

Sugiyono. (2015). Statistik Nonparametris Untuk Penelitian. Yogyakarta.

Susanto, H. (2016). Pengaruh Kepemimpinan Dan Motivasi Terhadap Kinerja Karyawan Cv. Adhi Baskoro Perkasa Pangkalanbun. Journal of 
Social And Political Of Science, 1-8.

Suwati, Y. (2013). Pengaruh Kompensasi Dan Motivasi Kerja Terhadap Kinerja Karyawan Pada Pt . Tunas Hijau Samarinda. Journal Ilmu Administrasi Bisnis, 1(1), 4155.

Widodo, B. H., \& Susanti, F. (2019). Pengaruh Human Relation (Hubungan Antar Manusia), Lingkungan kerja Terhadap Etos Kerja karyawan (Studi Kasus Pada PT. Pelindo Teluk Bayur Padang https://doi.org/10.31227/osf.io/d xm8a

Yudistira, D. S., \& Susanti, F. (2019). Pengaruh Motivasi Kerja Dan Budaya Kerja Terhadap Kinerja Karyawan Dinas Pemberdayaan Masyarakat Dan Desa, Pengendalian Penduduk Dan Keluarga Berencana Kabupaten Pesisir Selatan. https://doi.org/10.31227/osf.io/j $\mathrm{k} 54 \mathrm{~m}$ 